\title{
Challenges and Short-Term Solutions to Promote Food and Nutrition Security in COVID- 19 Pandemic
}

\author{
Majid Hajifaraji ${ }^{1,2 *}$ \\ ${ }^{1}$ Department of Food and Nutrition Policy and Planning Research, National Nutrition and Food Technology Research Institute, \\ Shahid Beheshti University of Medical Sciences, Iran
}

${ }^{2}$ Department of Nutrition and Health, National Academy of Medical Sciences, Iran

*Corresponding author: Majid Hajifaraji, Department of Food and Nutrition Policy and Planning Research, National Nutrition and Food Technology Research Institute, Shahid Beheshti University of Medical Sciences, Tehran, Iran

\section{ARTICLE INFO}

Received: 幽 December 16, 2020

Published: 㓞 December 23, 2020

Citation: Majid Hajifaraji. Challenges and Short-Term Solutions to Promote Food and Nutrition Security in COVID- 19 Pandemic. Biomed J Sci \& Tech Res 32(5)-2020. BJSTR. MS.ID.005308.

\section{ABSTRACT}

Sustainable food supply, which ensures the security of the individual, family and society, is one of the main tasks of the government, and an important right of the people, particularly in critical situations. The aim of this study was considering the challenges and short-Term solutions to promote food and nutrition security in critical situations such as Covid-19 Pandemic. We discussed the challenges and feasible solutions to reduce all the consequences of food and nutrition security and community promotion.

Keywords: Food and Nutrition Security; Challenges; Solutions; Community; Pandemic; Covid-19

\section{Introduction}

Ensuring food and nutrition security for all members of society is clearly noted and emphasized in the constitution of all countries. Sustainable food supply, which ensures the security of the individual, family and society, is one of the main tasks of the government, which is achieved with the participation of the people. Achieving this important right, in critical situations, can be disrupted and endangered for a group of people. Food security exists when all people have physical, economical, and accessible access to adequate, healthy, and nutritious food at all times, and meets the needs of a diet consistent with their preferences for a healthy and productive life. The design of food security and nutrition problems of households, resulting from the socioeconomical, and psychological consequences of the Covid-19 epidemic and to investigate the causes and provide appropriate short-term solutions to deal with its possible effects. In the current situation, millions of households use their potential to choose the household food basket, which is a function of access to food, income, health, taste and behavior patterns, and the family food table, which is the source of energy and nutrients. Provides the need to maintain normal cell metabolism, survival, growth, health, physical and mental fitness and longevity of family members. In various crises, food security is affected in the food and nutrition system, from production to supply and consumption of food. Thus, the consequence of this crisis is a threat to household income, a chaotic distribution and an imbalance in consumption.

Since the outbreak of the Covid-19 epidemic, the crisis has exacerbated food insecurity around the world. On the other hand, it should be noted that the occurrence of food insecurity and malnutrition by weakening the immune system increases the risk of mortality due to Covid-19. This insecurity is more acute in deprived areas and groups, including urban suburbs and poor rural communities, and requires immediate attention. The economic crisis caused by this epidemic and unemployment or the cessation of some jobs due to quarantine and the obligation to stay at home on the one hand has led to unemployment and reduced household income and on the other hand a disproportionate increase in food prices. This set has aggravated the social, economic and psychological problems of the society and reduced food security. At the same time, food safety from the stage of raw material production to processing and consumption is at risk and its monitoring and follow-up is necessary.

In various crises, food security is affected in the food and nutrition system, from production to supply and consumption of 
food. The dimensions of the issue in the context of the Covid-19 epidemic are as follows:

a) Disorders in the production, distribution, and supply chains of food and agricultural products

b) Exacerbation of various forms of malnutrition and its complications, including weakening of the immune system and increased risk of death

c) More threatening pandemics and the spread of unhealthy food and nutrition in disadvantaged areas or groups, including suburbs and rural areas.

d) Other dimensions of the epidemic economic crisis (rising unemployment, quarantine and forced housing, and declining economic access to food, especially for the vulnerable and lower-income households, and the onset or exacerbation of economic problems)., Social and psychological resulting.

e) Lack of access to agricultural and livestock inputs, including utility, quantity and cost for farmers and livestock in return for the cost of production.

f) Import of poor quality and unhealthy food in accordance with the standards in the form of smuggling or from official points of entry without considering the minimum standards.

g) This article is the result of hours of discussion by professors of related groups such as nutrition, food industry, agriculture, economics, epidemiology on the subject in which it has tried to reduce all the consequences, short-term solutions to reduce the consequences of all Provide feedback on food and nutrition security and community promotion.

h) Short-term solutions

i) Immediate formation of a food safety working group in the national headquarters for the fight against coronation, with the presence of all stakeholders and the formation of weekly meetings and follow-up of its approvals

j) Implementing the intervention model of food security package for low-income households based on the criteria for selecting households at risk of food insecurity and through provincial management and supervision in cooperation with national and international NGOs.

\section{ISSN: 2574-1241}

DOI: $10.26717 /$ BJSTR.2020.32.005308

Majid Hajifaraji. Biomed J Sci \& Tech Res

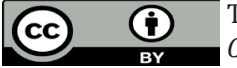

This work is licensed under Creative Commons Attribution 4.0 License

Submission Link: https://biomedres.us/submit-manuscript.php k) Provision and distribution of adequate food baskets or packages (with emphasis on domestic products) or through smart cards in a targeted manner, with priority given to lowincome households and vulnerable groups, especially pregnant mothers and children under 5, with Cooperation of support organizations and attracting the participation of donors through various means, including health care network, mosques and mobilization bases.

l) Allocating and subsidizing essential food items (such as dairy and protein products) from the place of taxation and value added of harmful goods and services, in order to regulate the purchase price of essential items, economic security and greater benefit to consumers.

m) Organizing and broadcasting targeted educational programs in the media, in order to increase food and nutrition literacy and the ability of households and individuals to ensure their food and nutrition security.

n) Empowering rural and suburban households, particularly women for agriculture and livestock and poultry farming, through training and providing seeds, livestock, and poultry to provide fruits, vegetables and animal protein.

o) Strengthen rural cooperatives and create markets for direct supply of agricultural products in order to support the production chain to consumption and increase people's purchasing power.

p) Strict control over the price of foodstuffs, especially essential items, and prevent their excessive increase.

q) Attract the support of non-governmental organizations and charities in order to implement food poverty reduction programs.

\section{Acknowledgement}

I would like to appreciate the unwavering cooperation and cooperation of professors and experts in related groups, including nutrition, food science and technology, agriculture, health economics, epidemiology.

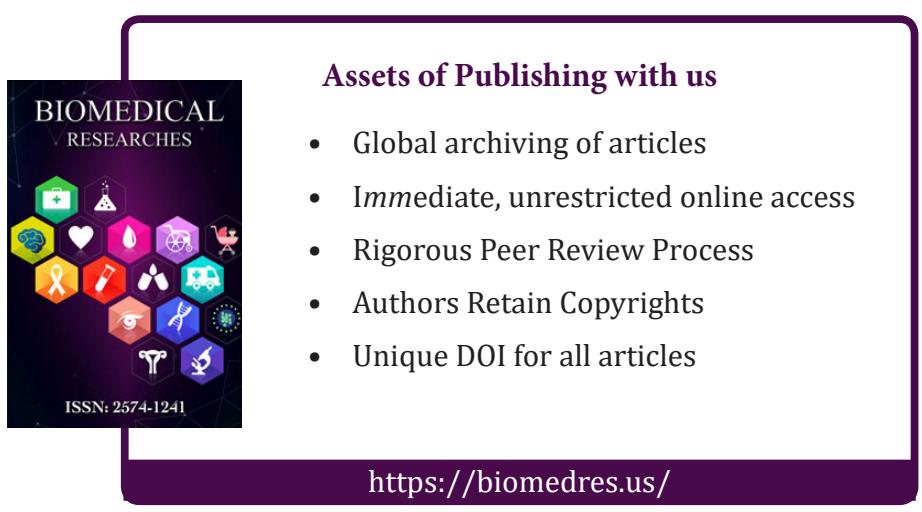

Copyright@ Majid Hajifaraji | Biomed J Sci \& Tech Res | BJSTR. MS.ID.005308. 